\title{
Molybdenum and Cobalt Application in Bean (Phaseolus vulgaris L.) with Two Fertilization Systems under No-Tillage
}

\author{
Jimmy Ocaña Reyes ${ }^{1}$, Sady García Bendezú ${ }^{1}$ and Amelia Huaringa Joaquín ${ }^{2}$ \\ 1. Academic Department of Soils, Agronomy Faculty, La Molina State University, Lima 12, Peru \\ 2. Academic Department of Fitotecnia, Agronomy Faculty, La Molina State University, Lima 12, Peru
}

\begin{abstract}
Molybdenum (Mo) and Cobalt (Co) play an important role in nitrogen (N) metabolism of grain legumes. Their applications to alkaline soils have been scarcely studied. A field experiment was set up to evaluate the Mo and Co application in common bean cv. Canario Centenario under two fertilization systems: inorganic fertilization and inoculation with Rhizobium etli. In each system, Mo and Mo + Co were applied by seed impregnation at doses of $1.36 \mathrm{~g} / \mathrm{kg}$ of seed for Mo and $0.26 \mathrm{~g} / \mathrm{kg}$ of seed for Co; a control for each fertilization system and an absolute control were included. Yield components, nodules characteristics and $\mathrm{N}$ content by grains and foliage were evaluated. A completely randomized block design with seven treatments and five replications was used. Mo application increased the grain yield, grain size, nodulation and $\mathrm{N}$ accumulation in grains under both fertilization systems. Mo increased the total $\mathrm{N}$ uptake by the plant in $35.4 \%$ and $26 \%$, for $\mathrm{N}$ fertilized and inoculated plants, respectively. Co application increased only nodules number and weight, and $\mathrm{N}$ content under inoculation. Mo application to beans cultivated in alkaline soils is recommended, but Co application is suitable only when beans are inoculated with rhizobia.
\end{abstract}

Key words: Mo, Co, N fertilization, Rhizobium etli, $\mathrm{N}$ content.

\section{Introduction}

Common beans are one of the most cultivated legumes in Peru, representing an average of 86 thousand ha yearly [1]. Despite its importance, its cultivation is mainly carried out by farmers with the limited access to economic and technological resources. Nitrogen $(\mathrm{N})$ requirement of bean varies between $80 \mathrm{~kg} / \mathrm{ha}$ and $100 \mathrm{~kg} / \mathrm{ha}$, although $150 \mathrm{~kg} / \mathrm{ha}$ may be required for higher yields. If $\mathrm{N}$ fertilization comes from nitric source, the partaking of molybdenum (Mo) as cofactor is essential. And, if $\mathrm{N}$ fertilization is through Rhizobium sp., not only Mo but also cobalt (Co) is important [2].

Mo is a cofactor of several enzymes involved in the metabolism of $\mathrm{N}$, e.g., nitrate reductase acting on the nitrate reduction to ammonia in the plant and nitrogenase involved in symbiotic $\mathrm{N}$ fixation [3]. So,

Corresponding author: Jimmy Ocaña Reyes, M.Sc., research field: soil and plant nutrition. increasing its activity could increase yield variables [3-6], biometrics parameters [4], $\mathrm{N}$ content [7] and nodules weight [2].

Co is part of cobalamin cofactor-dependent methionine synthase, ribonucleotide reductase and methylmalonyl CoA enzymes of Rhizobium sp., which influence in qualitative and quantitative characteristics of the root nodules $[8,9]$. Then, the addition of those microelements to plants could increase crop $[10,11]$.

It is generally considered that Mo availability increases with soil $\mathrm{pH}$ [9], thus, alkaline soils with $\mathrm{pH}$ over 8 , or limed soils are considered sufficient in Mo [8]. In contrast, Co availability is reduced by increasing soil $\mathrm{pH}$. Then, under experimental field conditions with slightly alkaline $\mathrm{pH}$, Co application would be beneficial to legumes inoculated with Rhizobium.

It was reported in Refs. [12-15] that the joint application of Mo and Co contributed to better results 
of the studied variables of legumes. However, in Refs. $[13,16,17]$, best results were obtained when such micronutrients were applied separately. Most studies have been conducted in acidic soils, thus the benefits of Mo and Co application in alkaline soils remain unclear. It is proposed that the Mo and Co application by seed impregnation can increase yield and $\mathrm{N}$ content in beans under inorganic $\mathrm{N}$ fertilization and inoculation with Rhizobium etli. Thus, an experiment was set up at the field level, under a no-tillage system, with the aim of evaluating the effect of Mo and Co application on nodulation, biometric variables and grain yield of common bean.

\section{Materials and Methods}

The experiment was carried out at the experimental field of La Molina University $\left(12^{\circ} 05^{\prime} 13^{\prime \prime} \mathrm{S} ; 76^{\circ} 56^{\prime} 42^{\prime \prime}\right.$ W), La Molina, Province of Lima, Peru. The field soil has deep, moderate permeability, good drainage, loamy, fine granular structure and friable moist consistency. The parameters of the soil were measured as the following: electrical conductivity $(\mathrm{EC})=0.54$ $\mathrm{dS} / \mathrm{m}, \mathrm{pH}=8.1$, soil organic matter $=1.18 \%$, extractable $\mathrm{P}($ Olsen$)=8.8 \mathrm{mg} / \mathrm{kg}$, extractable $\mathrm{K}=$ $228 \mathrm{mg} / \mathrm{kg}$, cation exchange capacity $(\mathrm{CEC})=18.38$ $\mathrm{cmol} / \mathrm{kg}$.

La Molina has a hot desert climate with winter fogs. Average monthly temperature during the crop season (September to January) ranged from $14.9^{\circ} \mathrm{C}$ to $23.9^{\circ} \mathrm{C}$, with the minimum and maximum temperatures of $12.5^{\circ} \mathrm{C}$ and $27.7^{\circ} \mathrm{C}$ during September and January, respectively. Cumulative rainfall and potential evapotranspiration were $6 \mathrm{~mm}$ and $502 \mathrm{~mm}$, respectively. Thus, irrigation was applied during the entire crop season.

Corn (Zea mays L.) was cultivated in the field during the previous season (autumn), and common bean (Phaseolus vulgaris L.) cv. Canario Centenario (shrub type with bright yellow grains), was selected for the spring season. Beans were planted by direct seeding two weeks after corn harvest. Sowing was done at a row distance of $0.8 \mathrm{~m}$ and plant distance of $0.25 \mathrm{~m}$, with three seeds in each hole, for a density of 150,000 plants/ha.

Two $\mathrm{N}$ fertilization systems were set up: inorganic fertilization and rhizobial inoculation. In each system, Mo and Mo + Co were applied by seed immersion at doses of $1.36 \mathrm{~g} / \mathrm{kg}$ seed for Mo and $0.26 \mathrm{~g} / \mathrm{kg}$ seed for Co. Ammonium molybdate $\left[\left(\mathrm{NH}_{4}\right)_{6} \mathrm{Mo}_{7} \mathrm{O}_{24} \cdot 4 \mathrm{H}_{2} \mathrm{O}, 54 \%\right.$ Mo] and cobalt sulfate $\left(\mathrm{CoSO}_{4} \cdot 7 \mathrm{H}_{2} \mathrm{O}, 20 \% \mathrm{Co}\right)$ were used as Mo and Co sources, respectively. Both salts were diluted in distilled water and bean seeds were immersed in the solutions $20 \mathrm{~min}$ before sowing. A control without micronutrient application for each fertilization system and an absolute control were also included, resulting in seven treatments.

In the inorganic fertilization treatments, $\mathrm{N}(80 \mathrm{~kg} / \mathrm{ha})$ was applied as ammonium nitrate. The dose was split in two fractions applied at $8 \mathrm{~d}$ and $50 \mathrm{~d}$ after the emergence of seeds of Canario Centenario bean. In the treatments with rhizobial inoculation, Rhizobium etli growing in a liquid medium containing $1 \times 10^{8}$ cells $/ \mathrm{mL}$ was used. The inoculum was added with gum arabic and impregnated to seed at a dose of 0.625 $\mathrm{mL} / \mathrm{kg}$ of seed. Both inorganic fertilization and rhizobial treatments were fertilized at planting with 60 $\mathrm{kg} / \mathrm{ha} \quad \mathrm{P}_{2} \mathrm{O}_{5}$ and $80 \mathrm{~kg} / \mathrm{ha} \quad \mathrm{K}_{2} \mathrm{O}$ using triple superphosphate and potassium chloride, respectively. Soil moisture was maintained close to field capacity through weekly irrigation. Leafminer outbreaks were controlled with application of $0.1 \%$ abamectin, and $0.1 \%$ tebuconazole was applied before flowering for prevention of bean rust.

Treatments were applied to plots consisting in $5 \mathrm{~m}$ long sections of five rows $\left(20 \mathrm{~m}^{2}\right)$. A completely randomized block design with seven treatments and five replications was used. Plant leaf area and nodule formation were evaluated at the beginning of flowering (58 d after sowing) in an evaluation area consisting in 4 $\mathrm{m}$ long sections of the three central rows in each plot. The number of nodules per plant and their weight were registered in 10 randomly selected roots. Grain yield 
and its components (number of pods per plant, number of grains per pod and 100-grain weight) were evaluated at harvest (132 d after sowing). Grain yield was calculated from the grain weight obtained from the plants in the evaluation area adjusted to $14 \%$ moisture. Grain components were evaluated from 10 plants randomly selected from the evaluation area. The shoot biomass was measured after harvest and harvest index was calculated.

Portions of shoots and grains were oven-dried at $70{ }^{\circ} \mathrm{C}$ to obtain the dry matter content, and then finely ground. $\mathrm{N}$ content was determined in both tissues by Kjeldahl digestion, and $\mathrm{N}$ partitioning in grains, shoots and the entire plant was calculated.

The values obtained from variables evaluation were further processed using ANOVA. The averages were compared by multiple comparison test of Tukey's honestly significant difference (HSD) with a significance level of $5 \%$. The Statistical Analysis System Program (SAS) was used for statistical analysis [18].

\section{Results and Discussion}

Results about the biometric variables and yield of bean (plant leaf area, pods per plant, grains per pod, 100 -grain weight and grain yield) are summarized in Table 1. Both inorganic $\mathrm{N}$ fertilization and rhizobial inoculation clearly increased leaf area, grain yield and its components, compared to unfertilized control, and inorganic $\mathrm{N}$ fertilization resulted in higher values compared to inoculated treatments. Inorganic $\mathrm{N}$ fertilization treatment with Mo addition showed the best result in all the above mentioned variables, among all treatments, probably due to the increase in nitrate reductase activity. It has been reported by Marschner [2] that applying Mo $5 \mu \mathrm{g} / \mathrm{plant}$, the enzymatic activity increased at 27.3 times.

In the inoculated bean treatments, the bean inoculated with Rhizobium etli with Mo addition (RhMo) showed the best effect in the increasing of leaf area, harvest index and yield, highlighting the important role of Mo on nitrogenase and xanthine oxidase/dehydrogenase activity in the atmospheric $\mathrm{N}$ reduction and purine metabolism to ureide, respectively [2]. However, there was no complementarity between Mo and Co, as the Co was added to RhMo, in contrary, leaf area decreased slightly. But, there was an increasing of 3.75 nodules per plant and a slight increasing in seed yield (8.52 $\mathrm{kg} / \mathrm{ha}$ ); Co application just favored the two reservoirs. These effects could be explained by that Co forms an essential part of the cobalamin coenzyme, which is dependent on the three enzymes for nodulation: methylmalonyl-CoA mutase, ribonucleotide reductase

Table 1 Effect of Mo and Co addition under two systems of $\mathbf{N}$ fertilization on biometric traits and yield components of bean.

\begin{tabular}{llllllll}
\hline Treatments & $\begin{array}{l}\text { Leaf area } \\
\left(\mathrm{dm}^{2}\right)\end{array}$ & $\begin{array}{l}\text { No. of } \\
\text { pods/plant }\end{array}$ & $\begin{array}{l}\text { No. of } \\
\text { grains/pods }\end{array}$ & $\begin{array}{l}\text { The weight of } \\
100 \text { grains }(\mathrm{g})\end{array}$ & $\begin{array}{l}\text { Total weight } \\
(\mathrm{kg} / \mathrm{ha})\end{array}$ & $\begin{array}{l}\text { Harvest index } \\
(\%)\end{array}$ & $\begin{array}{l}\text { Yield } \\
(\mathrm{kg} / \mathrm{ha})\end{array}$ \\
\hline Control & $8.22^{\mathrm{F}}$ & $8.80^{\mathrm{D}}$ & $3.20^{\mathrm{D}}$ & $40.19^{\mathrm{C}}$ & $1,433.70^{\mathrm{F}}$ & $47.00^{\mathrm{D}}$ & $679.74^{\mathrm{F}}$ \\
\hline Inorganic fertilization & & & & & & & \\
\hline- & $36.73^{\mathrm{C}}$ & $16.80^{\mathrm{C}}$ & $4.20^{\mathrm{ABC}}$ & $41.61^{\mathrm{BA}}$ & $3,647.50^{\mathrm{C}}$ & $52.00^{\mathrm{C}}$ & $1,881.96^{\mathrm{C}}$ \\
Mo & $45.23^{\mathrm{A}}$ & $32.40^{\mathrm{A}}$ & $5.00^{\mathrm{A}}$ & $42.35^{\mathrm{A}}$ & $5,287.50^{\mathrm{A}}$ & $51.00^{\mathrm{C}}$ & $2,716.00^{\mathrm{A}}$ \\
Mo + Co & $41.01^{\mathrm{B}}$ & $28.20^{\mathrm{B}}$ & $4.60^{\mathrm{AB}}$ & $42.22^{\mathrm{A}}$ & $4,680.00^{\mathrm{B}}$ & $51.00^{\mathrm{C}}$ & $2,402.90^{\mathrm{B}}$ \\
\hline Rhizobium etli $(\mathrm{Rh})$ & & & & & & & \\
\hline- & $25.37^{\mathrm{E}}$ & $11.20^{\mathrm{D}}$ & $3.40^{\mathrm{CD}}$ & $41.31^{\mathrm{B}}$ & $2,272.40^{\mathrm{E}}$ & $52.00^{\mathrm{BC}}$ & $1,191.92^{\mathrm{E}}$ \\
Mo & $35.20^{\mathrm{C}}$ & $16.20^{\mathrm{C}}$ & $4.00^{\mathrm{BCD}}$ & $41.46^{\mathrm{BA}}$ & $3,137.50^{\mathrm{D}}$ & $55.00^{\mathrm{A}}$ & $1,719.28^{\mathrm{D}}$ \\
Mo + Co & $30.97^{\mathrm{D}}$ & $16.40^{\mathrm{C}}$ & $4.20^{\mathrm{ABC}}$ & $41.79^{\mathrm{BA}}$ & $3,212.50^{\mathrm{D}}$ & $54.00^{\mathrm{BA}}$ & $1,727.80^{\mathrm{D}}$ \\
\hline
\end{tabular}

The values shown are average of five replications.

${ }^{\text {A-F }}$ Values within a column followed by the same letter are not significantly different for Tukey's HSD. 
Table 2 Effect of Mo and Co addition under two systems of $\mathbf{N}$ fertilization on nodulation by Rhizobium etli and $\mathbf{N}$ content in bean plants.

\begin{tabular}{|c|c|c|c|c|c|}
\hline Treatments & No. of nodules/plant & $\begin{array}{l}\text { Nodules weight } \\
\text { (mg/plant) }\end{array}$ & $\mathrm{N}$ in grains $\left(\mathrm{g} / \mathrm{m}^{2}\right)$ & Stubble N $\left(\mathrm{g} / \mathrm{m}^{2}\right)$ & Total N $\left(\mathrm{g} / \mathrm{m}^{2}\right)$ \\
\hline Control & $25.70^{\mathrm{C}}$ & $2.10^{\mathrm{D}}$ & $1.90^{\mathrm{F}}$ & $0.63^{\mathrm{C}}$ & $2.61^{\mathrm{G}}$ \\
\hline \multicolumn{6}{|c|}{ Inorganic fertilization } \\
\hline- & $14.70^{\mathrm{D}}$ & $2.40^{\mathrm{C}}$ & $5.60^{\mathrm{C}}$ & $1.80^{\mathrm{A}}$ & $7.44^{\mathrm{C}}$ \\
\hline Mo & $14.20^{\mathrm{D}}$ & $2.40^{\mathrm{C}}$ & $8.40^{\mathrm{A}}$ & $1.66^{\mathrm{A}}$ & $10.08^{\mathrm{A}}$ \\
\hline $\mathrm{Mo}+\mathrm{Co}$ & $16.50^{\mathrm{DC}}$ & $2.40^{\mathrm{C}}$ & $6.80^{\mathrm{B}}$ & $1.88^{\mathrm{A}}$ & $8.76^{\mathrm{B}}$ \\
\hline \multicolumn{6}{|c|}{ Rhizobium etli (Rh) } \\
\hline- & $40.20^{\mathrm{B}}$ & $2.30^{\mathrm{DC}}$ & $3.40^{\mathrm{E}}$ & $1.130^{\mathrm{B}}$ & $4.58^{\mathrm{F}}$ \\
\hline Mo & $48.50^{\mathrm{BA}}$ & $2.70^{\mathrm{B}}$ & $4.80^{\mathrm{D}}$ & $0.960^{\mathrm{B}}$ & $5.77^{\mathrm{E}}$ \\
\hline $\mathrm{Mo}+\mathrm{Co}$ & $52.20^{\mathrm{A}}$ & $2.90^{\mathrm{A}}$ & $5.10^{\mathrm{DC}}$ & $1.150^{\mathrm{B}}$ & $6.26^{\mathrm{D}}$ \\
\hline
\end{tabular}

The values shown are average of five repetitions.

A-F Values within a column followed by the same letter are not significantly different for Tukey's HSD.

and methionine synthase, involved in heme synthesis, DNA and protein, respectively [9]. Supplying Mo to the beans inoculated with Rhizobium etli, nodules number and weight increased in $88 \%$ and $37 \%$, respectively, which could be explained by the high Mo importance in symbiotic $\mathrm{N}$ fixation of legume, being an important cofactor of nitrogenase complex and xanthine oxidase, for $\mathrm{N}$ fixation and purine metabolism, respectively [9].

Pattanayak et al. [14] have done a field experiment on seed treatment of green gram at doses of $0.16 \mathrm{~g} / \mathrm{kg}$ and $0.008 \mathrm{~g} / \mathrm{kg}$ of seed for Mo and Co, respectively, results showed that the nodules number increased in a range of 122\%-144\%. However, Tenywa [19] reported that $\mathrm{Mo}$ at $390 \mathrm{~g} / \mathrm{ha}$ and $780 \mathrm{~g} / \mathrm{ha}$ applied to soybeans in acid soils did not significantly influence on the nodules number. In this study, Co application to RhMo treatment increased further nodules number in $107.6 \%$, indicating some synergy between Co and Mo for enhancing the activity of rhizobia.

Inorganic $\mathrm{N}$ application increased grain $\mathrm{N}$ uptake $\left(5.60 \mathrm{~g} / \mathrm{m}^{2}\right)$, thus resulting in an increased total $\mathrm{N}$ removal $\left(7.44 \mathrm{~g} / \mathrm{m}^{2}\right)$. The addition of Mo to $\mathrm{N}$ fertilized plants drastically increased $\mathrm{N}$ partitioning in grains and the whole plant to $8.4 \mathrm{~g} / \mathrm{m}^{2}$ and $10.08 \mathrm{~g} / \mathrm{m}^{2}$, respectively. Again, the enhanced activity of plant enzymes, such as nitrate reductase that plays an important role in $\mathrm{N}$ plant metabolism [2], can be claimed as an explanation. As reported by Pessoa et al. [4], the enzymatic activity increased 16 times by adding $80 \mathrm{~g} \mathrm{Mo/ha}$ to fertilized soybean crop with 60 $\mathrm{kg} \mathrm{N} / \mathrm{ha}$, compared with the control. Similarly, Marschner [2] found it possible for logarithmic increasing of the nitrate reductase activity, providing 5 mg Mo per wheat plant versus control. But, considering $\mathrm{N}$ source, such as urea, Mo applying would be unnecessary. So, when Mo foliar applying was at $20 \mathrm{~g} \mathrm{Mo} / \mathrm{ha}$ to a common bean crop, the increasing of seed $\mathrm{N}$ content (8\%) was not statistically significant [7].

When Rhizobium etli inoculated to bean, grain $\mathrm{N}$ and total $\mathrm{N}$ content increased at $3.4 \mathrm{~g} / \mathrm{m}^{2}$ and 4.58 $\mathrm{g} / \mathrm{m}^{2}$, respectively, while Mo adding to such treatment, $\mathrm{N}$ content increased at $4.8 \mathrm{~g} / \mathrm{m}^{2}$ and $5.77 \mathrm{~g} / \mathrm{m}^{2}$ in these variables, respectively (Table 2). These higher efficiencies could be explained by a higher activity of nitrogenase and xanthine oxidase enzymes in the dinitrogen reducing and purine catabolism, respectively [2]. Similarly, Vigna radiata, sowed in acid soil, increased proteins content by $2.02 \%$ and $10.7 \%$, with application of $1.5 \mathrm{~kg} / \mathrm{ha}$ Mo and $1 \mathrm{~kg} / \mathrm{ha}$ Co, respectively [20]. And, chickpea genotypes, sowed in soil with $\mathrm{pH} 7.98$, increased $\mathrm{N}$ content by $100.5 \%$, when applied with $0.5 \mathrm{~kg} / \mathrm{ha}$ Mo [21].

While, when Co supplies to beans treated with RhMo, seed $\mathrm{N}$ and total $\mathrm{N}$ content increased by $158 \%$ 
and $140 \%$, respectively. Similarly, in the mung bean those variables increased between $73 \%-75 \%$. And, it was also showed by González et al. [5] that Co application to $\mathrm{MoRh}$ treatment increased those variables further (73\%-90\%). However, the increasing of such parameter was favored with individual application of these micronutrients, but not jointly [16].

The results are interesting that neither Mo nor Co applications affected $\mathrm{N}$ partitioning of shoots, which was significantly higher under $\mathrm{N}$ fertilized plants.

\section{Conclusions}

The addition of Mo to N-fertilized and Rhizobium etli-inoculated Canario Centenario beans increased grain yields. Mo increased also $\mathrm{N}$ removal by grains and total $\mathrm{N}$ plant uptake, and had a positive effect on grain size. The highest yields were obtained in inorganic $\mathrm{N}$ treatment. On the contrary, the inclusion of Co in bean fertilization did not result in a further yield increase. As expected, inoculation of Rhizobium etli increased the number and weight of nodules and $\mathrm{N}$ content, while in inorganic content treatment, the increase were smaller and the number of nodules decreased.

When Mo was included in the fertilization of common bean inoculated with Rhizobium (under a no-till system), it can result in yields comparable to those obtained by N-fertilized beans. Thus, application of Mo by seed impregnation to bean cv. Canario Centenario, with inorganic fertilization or inoculated with $\mathrm{N}$ fixing bacteria, can result in yield increases that range from $500 \mathrm{~kg} / \mathrm{ha}$ to $800 \mathrm{~kg} / \mathrm{ha}$, which can be considered largely profitable for farmers in the central coast of Peru, characterized by alkaline and calcareous soils.

\section{Acknowledgments}

The authors wish to thank the Research Program in Grain Legumes and Oilseeds and the Laboratory of Microbial Ecology and Biotechnology "Marino
Tabusso" at Universidad Nacional Agraria La Molina (UNALM), for providing seeds, inoculants and technical guidance during this work.

\section{References}

[1] Ministry of Agriculture and Irrigation of Peru (MINAGRI). 2014. Agricultural Dynamics 2004-2013. General Direction of Monitoring and Evaluation of Polices. (in Spanish)

[2] Marschner, H. 1995. Mineral Nutrition of Higher Plants, 2nd ed.. London: Academic Press.

[3] Araújo, A., Peres, R., and Itamar, R. 2008. "Molybdenum Foliar Application, Productivity and Physiological Quality of Irrigated Bean Seeds.” Bragantia 67 (2): 377-84.

[4] Pessoa, S., Ribeiro, C., Chagas, M., and Cassini, A. 2001. "Nitrogenase and Nitrate Reductase Activity and Yield of Ouro Negro Bean in Response to Molybdenum Foliar Fertilization.” Brazilian Journal of Soil Science 25 (1): 217-24.

[5] González, E., Gálvez, L., Marino, D., Ladrera, R., Larrainzar, L., and Arrese-Igor, C. 2006. "Carbonated and Nitrogenous Metabolism in Nodules." In Nitrogen Fixation: Fundamentals and Applications. Pamplona, Spain: Spanish Society of Nitrogen Fixation, 194-206.

[6] Berton, F., Pires, C., Medeiros, C., and Klauberg, O. 2008. "Effect of Inoculation Associated to Leaf Sprayed $\mathrm{Co}+\mathrm{Mo}$ on the Yield and Grain Nutrients in Common Bean (Phaseolus vulgaris L.)." Brazilian Archives of Biology and Technology 51 (6): 1089-96.

[7] Fullin, E., Bauchour, M., Lani, J., and Furtado de Mendoça, N. 1999. "Nitrogen and Molybdenum in Irrigated Bean Fertilization." Brazilian Agricultural Research 34 (7): 1145-9.

[8] Havlin, J. L., Beaton, J. D., Tisdale, S. L., and Nelson, W. L. 1999. Soil Fertility and Fertilizers: An Introduction to Nutrient Management. New Jersey: Prentice Hall.

[9] Mengel, K., and Kirkby, E. 2001. Principles of Plant Nutrition, 5th ed.. Dordrecht: Kluwer Academic Publishers, 692.

[10] Junqueira Netto, A., Santos, O., Adair, H., and Vieira, C. 1977. "Preliminary Tests on the Molybdenum and Cobalt Application in Bean Culture (Phaseolus vulgaris L.)." Ceres 24 (136): 628-33.

[11] Gad, N. 2006. "Increasing the Efficiency of Nitrogen Fertilization through Cobalt Application to Pea Plant." Research Journal of Agriculture and Biological Sciences 2 (6): 433-42.

[12] Corrêa, V., Junqueira Netto, A., Rezende, M., and Andrade, L. 1990. "Effects of Rhizobium, Molybdenum 

with Two Fertilization Systems under No-Tillage

and Cobalt on Common Bean cv. Carioca." Brazilian Agricultural Research 25 (4): 513-9.

[13] Dechen, A., Haag, H., and Carmello, Q. 1991. "Function of Micronutrients in Plants." In: Micronutrients in Agriculture. Piracicaba: Brazilian Association for Research on Potash and Phosphate, 65-78.

[14] Pattanayak, S. K., Dash, D., Jena, M. K., and Kayak, R. K. 2000. "Seed Treatment of Green Gram with Molybdenum and Cobalt: Effect on Nodulation, Biomass Production and N Uptake in an Acid Soil." Journal of the Indian Society of Soil Science 48 (4): 769-73.

[15] Ferraris, G., and Couretot, L. 2004. "Evaluation of Inoculation and Different Doses of Cobalt and Molybdenum as Seed or Leaf Treatment in First Soybeans." Journal of Rural Development 9 (26): 5. (in Spanish)

[16] Mohandas, S. 1985. "Effect of Presowing Seed Treatment with Molybdenum and Cobalt on Growth, Nitrogen and Yield in Bean (Phaseolus vulgaris L.)." Plant and Soil 86 (2): 283-5.
[17] Marcondes, A., and Caires, E. 2005. "Molybdenum and Cobalt Application to Seed for Soybean Crop." Bragantia 64 (4): 687-94. (in Portuguese)

[18] SAS Institute Inc.. 2008. SAS/STAT User's Guide. Version 9.1. Cary, NC: SAS Institute.

[19] Tenywa, S. 1997. "Influence of Molybdenum and Cobalt Fertilization on Symbiotic Nitrogen Fixation Indicators in an Oxisol in Uganda." African Crop Science Journal 5 (1): 87-92.

[20] Awomi, T. A., Singh, A. K., Kumar, M., and Bordoloi, L. J. 2012. "Effect of Phosphorus, Molybdenum and Cobalt Nutrition on Yield and Quality of Mungbean (Vigna radiata L.) in Acidic Soil of Northeast India." Indian Journal of Hill Farming 25 (2): 22-6.

[21] Nawaz, K., Muhammad, T., Khitab, U., Dost, M., Imran, K., Kamran, R., Nazeer, A., and Saeed, A. 2014. "The Effect of Molybdenum and Iron on Nodulation, Nitrogen Fixation and Yield of Chickpea Genotypes (Cicer Arietinum L.)." IOSR Journal of Agriculture and Veterinary Science 7 (1): 63-79. 